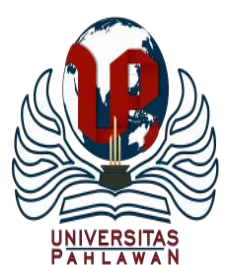

Edukatif : Jurnal Ilmu Pendidikan Volume 3 Nomor 4 Tahun 2021 Halm 1830 - 1837

EDUKATIF: JURNAL ILMU PENDIDIKAN

Research \& Learning in Education

https://edukatif.org/index.php/edukatif/index

\title{
Peningkatan Hasil Belajar Kognitif Melalui Model Discovery Learning Tema Perkembangan Teknologi Pada Siswa Sekolah Dasar
}

\author{
Apri Dwi Prasetyo ${ }^{1 凶}$, Muhammad Abduh ${ }^{2}$ \\ Universitas Muhammadiyah Surakarta, Indonesia ${ }^{1,2}$ \\ E-mail : apridwi1923@gmail.com ${ }^{1}, \underline{\text { ma123@ums.ac.id }}^{2}$
}

\begin{abstract}
Abstrak
Penelitian ini bertujuan untuk meningkatkan hasil belajar kognitif siswa kelas III menggunakan model discovery learning. Penelitian ini menggunakan metode penelitian tindakan kelas yang dilaksanakan sebanyak dua siklus. Setiap siklus dilaksanakan dalam dua pertemuan dengan empat tahap kegiatan yaitu, perencanaan, tindakan, observasi, dan refleksi.Subjek penelitian adalah siswa kelas III SD Negeri 3 Pandean dengan jumlah 35 orang. Teknik pengumpulan data yang digunakan adalah observasi, dokumentasi, dan tes. Hasil penelitian pra siklus menunjukkan bahwa hasil rata-rata persentase ketuntasan hasil belajar kognitif siswa sebesar $56,21 \%$ dengan predikat kurang, sedangkan pada siklus I memperoleh persentase ketuntasan sebesar 71,42\% dengan predikat cukup, kemudian meningkat sebesar $82,85 \%$ pada siklus II dengan predikat baik. Dengan demikian dapat disimpulkan bahwa penggunaan model discovery learning dapat meningkatkan hasil belajar kognitif pada tema perkembangan teknologi.
\end{abstract}

Kata Kunci: hasil belajar kognitif, model discovery learning, pendidikan dasar.

\section{Abstract}

This study aims to improve the cognitive learning outcomes of third grade students using the discovery learning model. This study uses classroom action research method which was carried out in two cycles. Each cycle was held in two meetings with four stages of activity, like planning, action, observation, and reflection. The research subjects were the third grade students of SD Negeri 3 Pandean with a total of 35 people. Observation, documentation, and tests were used as the data collection techniques. The results of the precycle research showed that the average percentage of students' cognitive learning outcomes was $56.21 \%$ with less predicate. While in the first cycle, the percentage of completeness was $71.42 \%$ with sufficient predicate, then increased by $82.85 \%$ in the second cycle with good predicate. Thus it can be concluded that the use of discovery learning models can improve students' cognitive learning outcomes on the theme of technological development.

Keywords: cognitive learning outcomes, discovery learning model, basic education.

Copyright (c) 2021 Apri Dwi Prasetyo, Muhammad Abduh

$\triangle$ Corresponding author

Email : apridwi1923@gmail.com

DOI : https://doi.org/10.31004/edukatif.v3i4.677

ISSN 2656-8063 (Media Cetak)

ISSN 2656-8071 (Media Online) 
1831 Peningkatan Hasil Belajar Kognitif Melalui Model Discovery Learning Tema Perkembangan Teknologi Pada Siswa Sekolah Dasar - Apri Dwi Prasetyo, Muhammad Abduh

DOI : https://doi.org/10.31004/edukatif.v3i4.677

\section{PENDAHULUAN}

Tantangan di era globalisasi di mana perkembangan teknologi semakin berkembang membuat guru harus mempersiapkan siswanya untuk beradaptasi dengan berbagai perkembangan di era revolusi industri. Kemampuan pendagogis guru sebagai pengajar dituntut untuk lebih mampu mendesain pembelajaran agar lebih menarik dan bermakna, kegiatan belajar mengajar harus diperluas melampaui batas-batas ruang kelas. (Daryanto, 2017:52) menyatakan bahwa karakteristik keterampilan guru abad 21 di mana era informasi menjadi ciri utamanya, yaitu: (1) Mampu memfasilitasi dan menginspirasi kreativitas belajar siswa, (2) Merancang kemudian mengembangkan pengalaman belajar dan assessment era digital, (3) Menjadi model cara belajar dan bekerja di era digital, (4) Mendorong dan menjadi model tanggung jawab dan masyarakat digital, (5) Berpartisipasi dalam pengembangan dan kepemimpinan professional.

Hal ini menuntut peran guru untuk mengembangkan kemampuan baik hard skill maupun soft skill pada siswa dalam pembelajaran di sekolah melalui inovasi dan memanfaatkan berbagai referensi yang ada di internet. Guru menyiapkan segala perangkat yang menunjang suatu proses pelaksanaan pembelajaran dan model atau metode yang di intergrasikan dengan pembelajaran abad 21, dengan mengembangkan keterampilan abad 21 dalam pembelajaran diharapkan setiap individu memilki keterampilan untuk hidup dengan berbagai peluang dan tantangan yang akan di hadapi di era kemajuan teknologi dan informasi. Dalam jurnal ilmiah (Septikasari, 2018) menjelaskan pentingnya penguasaan berbagai keterampilan abad 21 sebagai sarana kesuksesan dimana dunia berkembang dengan cepat dan dinamis. Kegiatan yang mendorong siswa untuk bekerja sama dan berkomunikasi harus tampak dalam setiap rencana pembelajaran yang dibuat oleh guru agar siswa dapat berpikir kritis dalam memecahkan suatu permasalahan secara efektif.

Berdasarkan hasil observasi permasalahan yang dijumpai di SD Negeri 3 Pandean yakni: (1) Kurang aktifnya siswa dalam kegiatan pembelajaran, (2) Siswa bosan dengan pembelajaran yang berlangsung (media pembelajaran yang kurang bervariatif), (3) Siswa kurang memberi respon terhadap pertanyaan yang diajukan guru, (4) Siswa belum memahami secara maksimal materi yang disampaikan sehingga hasil belajar kognitif rendah, dan (5) Kurangnya penerapan model pembelajaran yang cocok untuk karakteristik siswa karena guru masih dominan dengan model ceramah dan penugasan. Mengantisipasi masalah tersebut, dalam proses pembelajaran harus digunakan model pembelajaran yang sesuai agar hasil belajar kognitif siswa dapat meningkat. Stategi pembelajaran yang diharapkan peneliti adalah penggunaan model pembelajaran yang mampu membantu siswa menjadi aktif, kreatif, serta dengan mudah mempelajari konsep sehingga tujuan pembelajaran dapat tercapai. Untuk meningkatkan keaktifan dan hasil belajar siswa, dalam jurnal ilmiah (Ariyana, 2020) salah satu model pembelajaran yang dapat diterapkan sesuai dengan karakteristik siswa adalah discovery learning.

Menurut (Hosnan, 2016: 282) pengertian discovery learning ialah model pengembangan cara belajar aktif dengan mendapatkan dan mengkaji sendiri, maka hasil yang didapatkan bisa terus di ingat. Dengan menggunakan metode belajar ini, siswa juga dapat belajar berpikir menganalisa dan memecahkan masalahnya. Selanjutnya dalam jurnal (Wahyudi, dkk 2019) discovery learning merupakan suatu model untuk mengembangkan cara belajar siswa aktif dengan menemukan dan menyelidiki maka hasil yang diperoleh akan tahan lama dalam ingatan tidak akan mudah dilupakan siswa. Model discovery learning merupakan penemuan konsep dengan serangkaian data atau informasi yang didapatkan lewat pengamatan maupun percobaan (Hamalik, 2015: 29). Dari berbagai pendapat diatas dapat disimpulkan bahwa karakteristik model pembelajaran discovery learning antara lain: (1) mendalami dan menyelesaikan masalah untuk membentuk, menggabungkan, dan mengumumkan pengetahuan, (2) berfokus kepada siswa, dan (3) aktivitas menggabungkan pengetahuan baru dan pengetahuan yang telah ada sebelumnya.

Beberapa penelitian menunjukkan peningkatan hasil belajar kognitif dengan menggunakan model pembelajaran discovery learning. Diantaranya oleh (Azis dkk, 2017) pada penilaian hasil belajar kognitif 
1832 Peningkatan Hasil Belajar Kognitif Melalui Model Discovery Learning Tema Perkembangan Teknologi Pada Siswa Sekolah Dasar - Apri Dwi Prasetyo, Muhammad Abduh

DOI : https://doi.org/10.31004/edukatif.v3i4.677

siklus I rata-rata nilai mencapai 72,2 sedangkan penilaian hasil belajar siklus II rata-rata nilai mencapai 80,8. Sejalan pada penelitian tersebut (Pamungkas dkk, 2018) penerapan model pembelajaran discovery learning pada siswa kelas IV. Hasil penelitian menunjukkan peningkatan persentase hasil belajar kognitif siswa, pada pra siklus menunjukkan ketuntasan (41\%) dengan 15 siswa tuntas, kemudian meningkat pada siklus 1 menjadi (54\%) dengan 20 siswa tuntas, dan (81\%) dengan 30 siswa tuntas pada siklus II. Selanjutnya penelitian (Muslichah, 2021) Peningkatan hasil belajar siswa pada keadaan awal ketuntasan belajar siswa adalah 43,75\% dengan rata-rata klasikal adalah 58,71 meningkat menjadi 46,87\% dengan rata-rata klasikal 61,43 pada siklus I, meningkat menjadi 75,00\% dengan rata-rata klasikal 70,71 pada siklus II dan meningkat kembali menjadi $85,71 \%$ dengan rata-rata klasikal 84,17 pada siklus III. Demikian pembelajaran discovery learning dapat meningkatkan hasil belajar siswa pada siswa kelas 4 SDN Siberuk Tahun Pelajaran 2020/2021.

Perbedaan atau keunikan penelitian ini dibanding sebelumnya antara lain dalam proses pembelajaran pada penelitian sebelumnya hanya sebatas menerapkan model pembelajaran discovery learning untuk meningkatkan hasil belajar, sedangkan pada penelitian ini model pembelajaran discovery learning dikombinasikan dengan kecakapan abad 21 yakni baik siswa ataupun guru harus mengembangkan keterampilan berpikir kreatif (creative thinking), berpikir kritis dan pemecahan masalah (critical thinking and problem solving), komunikasi (communication), dan berkolaborasi (collaboration) atau yang biasa disebut dengan $4 \mathrm{C}$.

Berdasarkan permasalahan observasi pada SD Negeri 3 Pandean, dapat diasumsikan bahwa pembelajaran yang dilakukan belum maksimal. Perlu adanya perbaikan pembelajaran yang tepat untuk meningkatkan keaktifan belajar siswa. Solusi untuk meningkatkan masalah tersebut yaitu dengan menggunakan model pembelajaran yang inovatif. Model pembelajaran discovery learning adalah model pembelajaran yang di dalam proses pembelajaran menggunakan masalah dalam mencapai tujuan penelitian yang akan dibahas oleh peneliti, maka disusun hipotesis tindakan pada penelitian ini adalah: (1) mendeskripsikan langkah-langkah sintaks penerapan model pembelajaran discovery learning untuk meningkatkan hasil belajar kognitif pada siswa kelas III SD Negeri 3 Pandean, (2) meningkatkan rata-rata nilai hasil belajar kognitif pada muatan pembelajaran tematik dengan menggunakan model discovery learning pada siswa kelas III SD Negeri 3 Pandean.

\section{METODE PENELITIAN}

Jenis penelitian yang digunakan pada penelitian ini adalah penelitian tindakan kelas (PTK). Menurut (Aqib, 2011: 3) penelitian tindakan kelas adalah penelitian yang dilakukan oleh guru di kelasnya sendiri melalui refleksi diri dengan tujuan untuk memperbaiki kinerjanya sehingga hasil belajar siswa meningkat. Sedangkan menurut (Kusuma, 2011: 60) penelitian tindakan kelas adalah penelitian yang dilakukan ketika sekelompok orang (siswa) di identifikasi permasalahannya, kemudian peneliti (guru) menetapkan suatu tindakan untuk mengatasinya. Jadi dapat disimpulkan tujuan PTK untuk mengubah perilaku pengajaran guru, perilaku siswa di kelas, peningkatan atau perbaikan praktik pembelajaran, dan atau mengubah kerangka kerja melaksanakan pembelajaran kelas yang diajar oleh guru tersebut sehingga terjadi peningkatan layanan profesional guru dalam menangani proses pembelajaran.

Penelitian ini dilakukan secara kolaboratif dan partisipatif. Kolaboratif berarti peneliti bekerjasama dengan guru kelas, sedangkan partisipatif berarti peneliti dibantu teman sejawat (observer). Penelitian ini dimaksudkan untuk memberikan informasi bagaimana cara untuk meningkatkan hasil belajar kognitif siswa pada materi tema perkembangan teknologi dengan model discovery learning. Oleh sebab itu, penelitian ini difokuskan pada tindakan-tindakan sebagai usaha untuk meningkatkan kompetensi kognitif siswa. Pelaksanaan penelitian ini dilakukan dengan beberapa siklus, serta dengan menggunakan model spiral sesuai 
1833 Peningkatan Hasil Belajar Kognitif Melalui Model Discovery Learning Tema Perkembangan Teknologi Pada Siswa Sekolah Dasar - Apri Dwi Prasetyo, Muhammad Abduh

DOI : https://doi.org/10.31004/edukatif.v3i4.677

dengan yang dikemukakan oleh Kurt Lewin dalam (Mulyatiningsih, 2014: 243) yang terdiri dari perencanaan, observasi \& tindakan serta refleksi. Prosedur pada setiap siklus saling berkesinambungan.

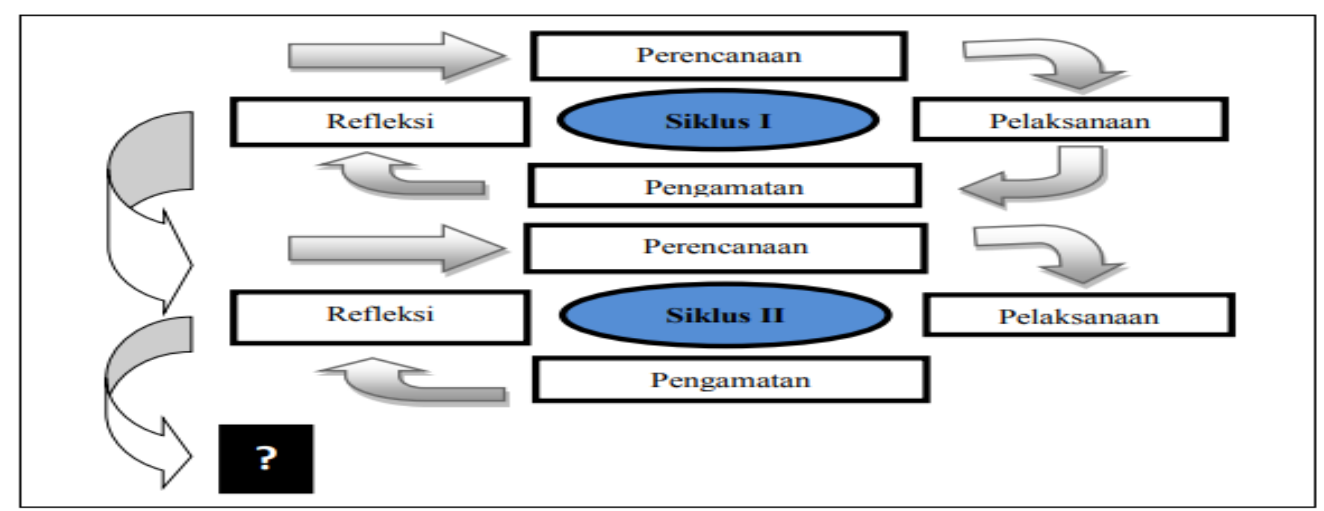

Gambar 1. Bagan Model Spiral oleh Kurt Lewin

Subjek dalam penelitian merupakan siswa kelas kelas III SD Negeri 3 Pandean, Kecamatan Ngemplak, Kabupaten Boyolali. Jumlah siswa kelas III berjumlah 35, dengan rincian 20 siswa laki-laki dan 15 siswa perempuan. Alasan dipilihnya kelas ini karena berdasarkan observasi dan wawancara memiliki hasil belajar kognitif yang lebih rendah dibandingkan dengan kelas yang lainnya. Objek dalam penelitian ini adalah masalah rendahnya hasil belajar kognitif siswa, kemudian dicarikan solusi untuk mengatasinya dengan menerapkan model pembelajaran discovery learning untuk meningkatkan hasil belajar kognitif siswa.

Teknik pengumpulan data digunakan untuk mengumpulkan data sesuai tata cara penelitian sehingga diperoleh data yang dibutuhkan. Menurut (Sugiyono, 2018: 224) teknik pengumpulan data merupakan langkah yang paling strategis dalam penelitian, karena tujuan utama dari penelitian adalah mengumpulkan data. Teknik yang digunakan untuk mengumpulkan data pada penelitian ini yang berkaitan dengan hasil belajar siswa yaitu : (1) Observasi digunakan untuk mengetahui keaktifan dan perilaku siswa selama proses pembelajaran berlangsung, (2) Wawancara merupakan teknik pengumpulan data yang dilakukan dengan cara memberikan pertanyaan atau pernyataan tertulis kepada responden untuk dijawab. Wawancara dilakukan dengan mengajukan pertanyaan kepada guru kelas untuk mengetahui karakter siswa dan hasil belajar siswa sebelum melakukan penelitian tindakan kelas, (3) Dokumentasi dilakukan untuk memperoleh data awal hasil belajar kognitif siswa yang sudah ada, (4) Tes umumnya bersifat mengukur, dalam penelitian ini akan menggunakan soal evaluasi untuk mengukur hasil belajar kognitif yang dicapai siswa.

Teknik analisis data yang digunakan dalam penelitian ini adalah teknik analisis Miles dalam (Sugiyono, 2018: 335) yang terdiri atas empat tahapan yang harus dilakukan diantaranya: Data collection (pengumpulan data), Data reduction (reduksi data), Data display (penyajian data), Conclusion drawing/verification (kesimpulan verivikasi). Pengumpulan data dapat dilakukan dengan banyak cara dan juga dengan alat bantu apapun untuk dapat membantu mengingat data. Selanjutnya data yang diperoleh dianalisis melalui tahap-tahap sebagai berikut: (1) Pengumpulan data dilakukan saat pelaksanaan pembelajaran, (2) Reduksi data meliputi penyeleksian dan penggolongan data sedangkan penyajian data dilakukan dalam rangka mengorganisasikan data yang merupakan penyusunan informasi secara sistematik dari hasil reduksi data, (3) Penarikan kesimpulan merupakan upaya pencarian makna data, mencatat keteraturan dan penggolongan data.

Prosedur Penilitian dalam penelitian ini meliputi: (1) Perencanaan, pada tahapan ini dilakukan pengamatan terhadap proses kegiatan belajar mengajar, mengidentifikasi masalah yang ditemukan saat belajar, menyiapkan dan menyusun instrumen penelitian berupa: RPP, media pembelajaran, bahan ajar, LKPD, alat instrumen evaluasi, lembar penilaian hasil belajar kognitif siswa dan lembar observasi pelaksanaan model pembelajaran discovery learning, (2) Pelaksanaan, pada tahap ini merupakan tahap pelaksanaan pembelajaran dengan menggunakan model pembelajaran discovery learning dan pada tahapan ini dilakukan pengumpulan data dari kegiatan proses kegiatan belajar, lembar observasi dan hasil dokumentasi. 
1834 Peningkatan Hasil Belajar Kognitif Melalui Model Discovery Learning Tema Perkembangan Teknologi Pada Siswa Sekolah Dasar - Apri Dwi Prasetyo, Muhammad Abduh

DOI : https://doi.org/10.31004/edukatif.v3i4.677

Pada siklus 1 menggunakan perangkat pembelajaran I dan II untuk 2 kali pertemuan. Sedangkan siklus 2 dengan menggunakan perangkat pembelajaran III dan IV untuk 2 kali pertemuan, (3) Pengamatan, pada tahap ini berpedoman dengan lembar observasi yang telah dibuat. Pada tahap pengamatan, hal yang diamati meliputi langkah-langkah sintaks pelaksanaan model pembelajaran discovery learning. Untuk pengamatan siswa meliputi kemampuan menulis dan lisan dalam mengerjakan LKPD secara berkelompok, selanjutnya dari soal evaluasi untuk mengukur tingkat pemahaman materi yang sudah dipahami oleh siswa secara individu, (4) Refleksi, Pada tahap ini adalah proses pengumpulan data dan kemudian dianalisis untuk pengambilan hasil penelitian dan kesimpulan. Hasil analisis di diskusikan dengan kolaborator yaitu guru pengajar, sehingga dapat ditentukan perlu tidaknya untuk melakukan perbaikan rencana pada siklus berikutnya apabila hasil belajar kognitif siswa belum terlihat mengalami peningkatan. Namun apabila hasil belajar kognitif siswa mengalami peningkatan sesuai dengan indikator keberhasilan maka siklus dihentikan. Adapun yang menjadi indikator pencapaian dalam penelitian tindakan kelas ini adalah diharapkan dapat meningkatkan hasil belajar kognitif siswa mencapai $80 \%$ (predikat baik) dari 35 siswa.

Tabel 1. Indikator Capaian Hasil Belajar Kognitif

\begin{tabular}{cccc}
\hline Tingkat Penguasaan & Nilai Huruf & Bobot & Predikat \\
\hline $\mathbf{1}$ & $\mathbf{2}$ & $\mathbf{3}$ & $\mathbf{4}$ \\
\hline $86 \%-100 \%$ & $\mathrm{~A}$ & 4 & Sangat Baik \\
\hline $76 \%-85 \%$ & $\mathrm{~B}$ & 3 & Baik \\
\hline $60 \%-75 \%$ & $\mathrm{C}$ & 2 & Cukup \\
\hline $55 \%-59 \%$ & $\mathrm{D}$ & 1 & Kurang \\
\hline$\leq 54 \%$ & $\mathrm{E}$ & \multicolumn{2}{c}{ Sumber : (Syah, 2017: 223) }
\end{tabular}

Indikator keberhasilan di dalam pelaksanaan penelitian ini dipandang berhasil apabila sudah memenuhi keberhasilan tindakan yaitu hasil belajar kognitif siswa melalui penerapan model discovery learning tema perkembangan teknologi kelas III di SD Negeri 3 Pandean dengan persentase mencapai $80 \%$ (berkriteria tinggi) dari 35 siswa. Indikator proses pembelajaran dalam penelitian ini akan dilihat dari persentase keberhasilan tindakan yang didasarkan pada data skor yang diperoleh dari hasil siswa siswa mengerjakan soal evaluasi secara mandiri.

\section{HASIL PENELITIAN DAN PEMBAHASAN}

Berdasarkan pembelajaran yang telah dilakukan dari awal, siklus I hingga pada siklus II, hasil belajar kognitif siswa mengalami peningkatan yang baik. Hasil penelitian tindakan kelas diperoleh kesimpulan bahwa tindakan belajar dengan model discovery learning dapat meningkatkan hasil belajar kognitif siswa. Berikut peneliti sajikan dalam bentuk tabel sebagai berikut:

Tabel 2. Data Hasil Belajar Kognitif Siswa

\begin{tabular}{cccc}
\hline & Pra Siklus & Siklus I & Siklus II \\
\hline Nilai rata-rata & 46,37 & 71,70 & 82,67 \\
\hline Jumlah siswa tuntas & 16 & 25 & 29 \\
\hline Jumlah siswa tidak tuntas & 19 & 10 & 6 \\
\hline Persentase yang tuntas & $45,71 \%$ & $71,42 \%$ & $82,85 \%$ \\
\hline Persentase yang tidak tuntas & $54,29 \%$ & $28,58 \%$ & $17,15 \%$ \\
\hline
\end{tabular}

Berdasarkan tabel di atas menunjukkan peningkatan persentase hasil belajar kognitif siswa dari tindakan pra siklus hingga siklus II. Hasil pra siklus sebanyak 16 siswa $(45,71 \%)$ memperoleh hasil yang 
1835 Peningkatan Hasil Belajar Kognitif Melalui Model Discovery Learning Tema Perkembangan Teknologi Pada Siswa Sekolah Dasar - Apri Dwi Prasetyo, Muhammad Abduh

DOI : https://doi.org/10.31004/edukatif.v3i4.677

tuntas dan 19 siswa $(54,29 \%)$ yang tidak tuntas. Pada siklus I mengalami peningkatan sebanyak 25 siswa $(71,42 \%)$ yang tuntas dan 10 siswa $(28,58 \%)$ yang tidak tuntas. Sedangkan pada siklus II mengalami peningkatan sebanyak 29 siswa $(82,85 \%)$ yang tuntas dan 6 siswa $(17,15 \%)$ yang tidak tuntas.

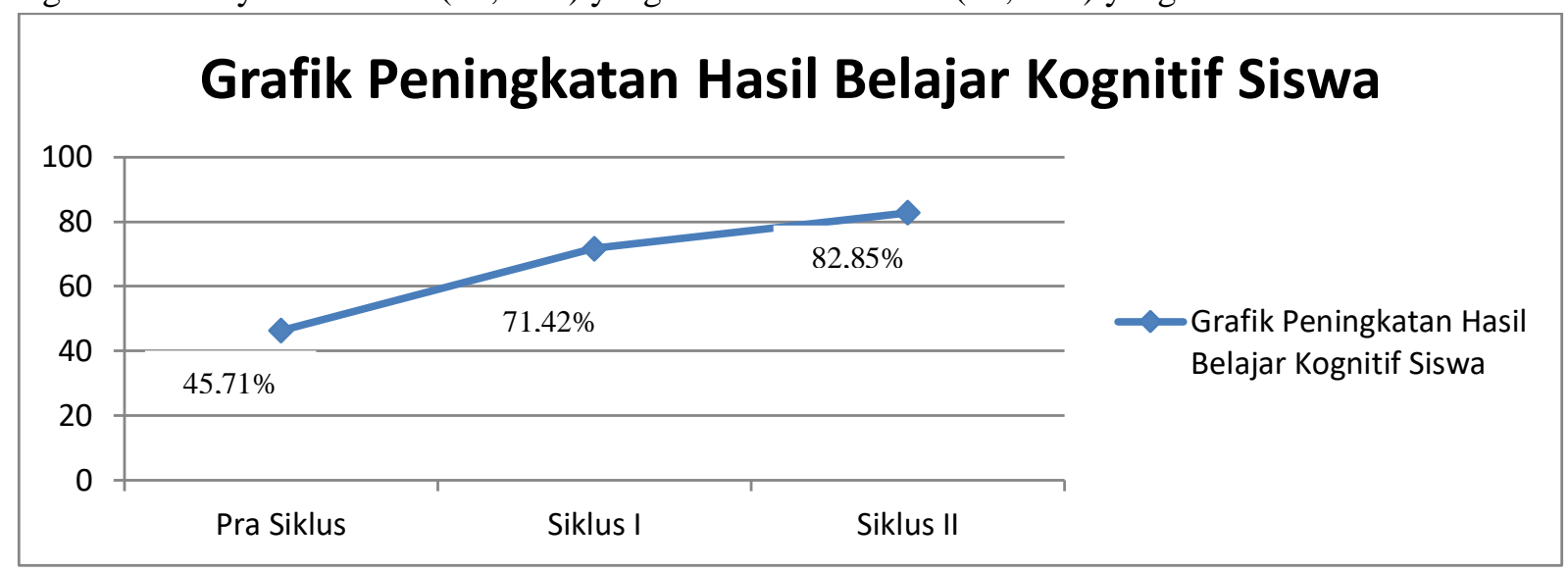

Gambar 2. Grafik Peningkatan Hasil Belajar Kognitif Siswa

Data hasil penelitian menunjukkan bahwa adanya peningkatan dari hasil belajar kognitif siswa dari pra siklus, siklus I hingga siklus II. Hal ini disebabkan karena sebagian besar siswa mampu memenuhi kriteria ketuntasan minimal dari setiap mupel yang disajikan dalam tema perkembangan teknologi yang terdiri dari Bahasa Indonesia, PPKn, dan Matematika. Hal ini menunjukkan bahwa dengan menerapkan model pembelajaran discovery learning dapat meningkatkan hasil belajar kognitif pada siswa kelas III SD Negeri 3 Pandean Tahun Ajaran 2020/2021.

Pada penelitian ini juga memiliki kesesuaian dengan penelitian lain, salah satunya penelitian yang dilakukan oleh (Cintia dkk, 2018) penerapan model discovery learning untuk meningkatkan kemampuan berpikir dan hasil belajar tematik di kelas V. Persentase keaktifan siswa 71,80\% di siklus I dan meningkat kembali menjadi $84,60 \%$ di siklus II. Peningkatan tersebut terjadi karena guru telah menerapkan model pembelajaran sesuai sintaknya dan dapat memancing siswa untuk terlibat aktif dalam pembelajaran sehingga siswa dapat memahami materi secara leluasa. Selanjutnya penelitian dari (Kanna dkk, 2018) mengungkapkan hasil penelitian tentang penerapan model pembelajaran discovery learning untuk meningkatkan hasil belajar pada mata pelajaran IPA kelas V SD. Hasil penelitian menunjukkan bahwa model pembelajaran discovery learning dapat meningkatkan hasil belajar kognitif siswa dalam proses pembelajaran pada siklus I sebesar $56 \%$ dengan kategori sedang meningkat menjadi 92\% pada siklus II dengan kategori tinggi.

Penerapan model pembelajaran discovery learning siswa diajak terlibat langsung dalam proses pembelajaran dengan mendapatkan dan mengkaji sendiri, maka hasil yang didapatkan bisa terus di ingat. Dengan menggunakan metode belajar ini siswa juga dapat belajar berpikir menganalisa dan memecahkan masalahnya dengan meleburkan pengetahuan baru dan pengetahuan yang telah ada sebelumnya. Peran guru dalam pembelajaran adalah sebagai fasilitator menyediakan bahan dan pengalaman belajar kemudian mendorong siswa untuk melaksanakan tugas dan memotivasi agar tetap semangat melaksanakan kewajibannya sebagai seorang pelajar. Kegiatan belajar berbasis discovery learning dapat membantu siswa dalam memahami konsep, arti, dan hubungan melalui proses intuitif untuk akhirnya sampai kepada suatu kesimpulan. Proses pembelajaran dilakukan secara membentuk kelompok belajar untuk berdiskusi.

Penelitian yang telah dilaksankan ini tidak terlepas dari berbagai keterbatasan. Keterbatasan yang pertama adalah penelitian belum bisa mengukur secara lengkap hasil belajar siswa yang meliputi tiga ranah yaitu ranah afektif, ranah kognitif, dan ranah psikomotorik. Penelitan ini hanya ditujukan untuk mengukur hasil belajar pada ranah kognitif dan ranah afektif saja. Keterbatasan kedua dalam proses penelitian ini tidak 
1836 Peningkatan Hasil Belajar Kognitif Melalui Model Discovery Learning Tema Perkembangan Teknologi Pada Siswa Sekolah Dasar - Apri Dwi Prasetyo, Muhammad Abduh

DOI : https://doi.org/10.31004/edukatif.v3i4.677

melibatkan tentang faktor internal siswa yang meliputi minat dan bakat dari siswa yang kemungkinan faktorfaktor ini mempengaruhi peningkatan kompetensi siswa dalam kegiatan pembelajaran.

Makna sumbangan yang bisa diberikan terhadap kemajuan ilmu pengetahuan, di antaranya: (1) diharapkan para guru dalam kegiatan belajar mengajar dapat memilih model pembelajaran yang tepat agar memicu semangat dan aktifitas belajar siswa, seperti implementasi model discovery learning yang dapat menciptakan suatu pembelajaran yang bermakna, (2) melalui penerapan model discovery learning, guru harus bersikap sebagai fasilitator bukan sebagai informator, sehingga siswa dapat merasakan bahwa pengetahuan yang diperoleh merupakan hasil dari rangkaian suatu proses pembelajaran, (3) guru sebaiknya memberikan kesempatan yang banyak kepada siswa untuk berperan aktif dalam pembelajaran dengan memberikan stimulus, (4) pembelajaran dengan menggunakan model discovery learning dapat dilaksanakan semua guru yang mempunyai permasalahan yang sama, dengan didasari dedikasi, kreativitas, serta sarana dan prasarana yang memadai.

\section{KESIMPULAN}

Berdasarkan penilitian yang dilakukan dapat disimpulkan bahwa: (1) Model pembelajaran discovery learning dengan sintaks pada tahap awal siswa diberi stimulasi atau pemberian rangsangan, kemudian siswa mengidentifikasi masalah, mengupulkan data, setelah pengumpulan data siswa mengolah, kemudian siswa melakukan pembuktian terhadap data yang diperoleh, dan pada tahap terakhir siswa menarikan kesimpulan. Langkah-langkah model pembelajaran discovery learning tersebut dapat meningkatkan hasil belajar kognitif siswa pada muatan pembelajaran tematik materi perkembangan teknologi kelas III SD Negeri 3 Pandean. (2) Hasil penelitian menunjukkan bahwa ada peningkatan hasil rata-rata keaktifan belajar siswa secara klasikal yang dilakukan dari tindakan pra siklus ke siklus I dan ke siklus II. Persentase rata-rata hasil belajar kognitif siswa pada pra siklus sebesar 41,53\% dengan predikat "rendah". Pada siklus I persentase rata-rata hasil belajar kognitif siswa meningkat sebesar $60,91 \%$ berada pada predikat "sedang". Sedangkan pada siklus II persentase rata-rata hasil belajar kognitif siswa meningkat sebesar $82,85 \%$ berada pada predikat "baik". Dari hasil yang diperoleh pada tindakan siklus II dapat dikatakan telah memenuhi kriteria keberhasilan yang telah ditetapkan. Dengan demikian dapat disimpulkan bahwa model pembelajaran discovery learning dapat meningkatkan hasil belajar kognitif pada siswa kelas III tema perkembangan teknologi di SD Negeri 3 Pandean Tahun Pelajaran 2020/2021.

\section{UCAPAN TERIMA KASIH}

Penulis dalam menyusun penelitian ini mengucapkan puji syukur kepada Allah SWT atas segala limpahan rahmat dan hidayah dalam menyusun penelitian ini. Peneliti mengucapkan terima kasih kepada kepala sekolah SD Negeri 3 Pandean yang telah memberikan izin untuk melakukan penelitian, serta dosen pembimbing PPG FKIP UMS, dan guru pamong PPG FKIP UMS yang telah memberikan bimbingan dan arahannya. Semoga penelitian yang disusun ini dapat bermanfaat bagi semua pihak.

\section{DAFTAR PUSTAKA}

Ariyana, 2020. The Application of Discovery Learning Models in Learning to Write Descriptive Texts. Journal of English Education and Teaching (JEET). Volume 4 number 3, September 2020 page 401-412.

Aqib, Zainal, dkk. 2011. Penelitian Tindakan Kelas Untuk Guru SD, SLB, Dan TK. Bandung: Yrama Widya.

Azis, Dkk. 2017. Penerapan Model Discovery Learning Untuk Meningkatkan Keaktifan Dan Hasil Belajar Siswa Pada Subtema Menjaga Keselamatan Di Perjalanan (Universitas Pasundan). 
1837 Peningkatan Hasil Belajar Kognitif Melalui Model Discovery Learning Tema Perkembangan Teknologi Pada Siswa Sekolah Dasar - Apri Dwi Prasetyo, Muhammad Abduh

DOI : https://doi.org/10.31004/edukatif.v3i4.677

Cintia N.I, Kristin F \& Anugraheni I. 2018. "Penerapan Model Pembelajaran Discovery Learning Untuk Meningkatkan Kemampuan Berpikir Kritis Dan Hasil Belajar Siswa.” Jurnal Ilmu Pendidikan 1 (1): 23. https://doi.org/10.23887/jpk.v1i1.12808.

Daryanto, Karim Syaiful. 2017. Pembelajaran Abad 21. Gava Media.Yogyakarta.

Dimyati \& Mudjiono. 2015. Belajar Dan Pembelajaran. Jakarta: Rineka Cipta.

Hamalik, Oemar. 2015. Kurikulum Dan Pembelajaran. Jakarta: Bumi Aksara.

Hosnan. 2016. Pendekatan Saintifik Dan Kontekstual Dalam Pembelajaran Abad 21. Bogor: Ghalia Indonesia.

Kanna, Rialen, Firosalia Kristin, and Indri Anugraheni. 2018. "Penerapan Model Pembelajaran Discovery Learning Untuk Meningkatkan Kreativitas Dan Hasil Belajar Pada Mata Pelajaran IPA Kelas V SD." Kalam Cendekia $\quad 6 \quad$ (4.1): http://jurnal.fkip.uns.ac.id/index.php/pgsdkebumen/article/view/11960/8532.

Kusuma, Wijaya. 2011. Penelitian Tindakan Kelas. Jakarta: PT Indeks.

Muslichah, Siti. 2021. "Peningkatan Hasil Belajar Siswa Tema 5 Pahlawanku Sub-Tema 3 Sikap-Sikap Kepahlawanan Dengan Model Discovery Learning Pada Siswa Kelas 4 SDN Siberuk Tahun Pelajaran 2020/2021." Educatif: Journal of Education Research 3(3), 2021, 37-46. 3 (20): 37-46.

Pamungkas, Andika Dinar, Firosalia Kristin, and Indri Anugraheni. 2018. "Meningkatkan Keaktifan Dan Hasil Belajar Siswa Melalui Model Pembelajaran Problem Based Learning (PBL) Pada Siswa Kelas 4 SD.” NATURALISTIC : Jurnal Kajian Penelitian Pendidikan Dan Pembelajaran 3 (1): 287-93.

Septikasari R \& Nugraha R. 2018. Keterampilan 4c abad 21 dalam pembelajaran pendidikan dasar. Jurnal Tarbiyah Al-Awlad, Volume VIII Edisi 02 2018, hlm 112-122.

Sudjana, Nana. 2016. Penelitian Hasil Proses Belajar Mengajar. Bandung: Remaja Rosda Karya.

Sugiyono. 2018. Metode Penelitian Pendidikan Pendekatan Kuantitatif, Kualitatif, Dan R\&D. Bandung: Alfabeta.

Suryosubroto, B. 2009. Proses Belajar Mengajar Di Sekolah. Jakarta: PT Reneka Cipta.

Syah, Muhibbin. 2017. Psikologi Pendidikan Dengan Pendekatan Baru. Bandung: PT. Remaja Rosdakarya.

Wahyudi, Roni, Rukmini D \& Bharati D.A.L. 2019. Developing Discovery Learning-Based Assessment Module to Stimulate Critical Thinking and Creativity of Students' Speaking Performance. English Education Journal EEJ 9 (2) (2019) 172 - 180. 